Original Research

\title{
Driving Factors and Prediction of Rock Desertification of Non-Tillage Lands in a Karst Basin, Southwest China
}

\section{Xianfei Huang ${ }^{1,2 \#,}$ Zhenming Zhang ${ }^{1,3 \#,}$ Yunchao Zhou ${ }^{1 *}$, Xingfu Wang ${ }^{2}$, Jiachun Zhang ${ }^{4}$, Xinwei Zhou ${ }^{4}$}

\author{
${ }^{1}$ Institute for Forest Resources \& Environment of Guizhou, Key Laboratory of Forest Cultivation in Plateau Mountain \\ Area, College of Forestry, Guizhou University, Guiyang 550025, P. R. China \\ ${ }^{2}$ Guizhou Provincial Key Laboratory for Environment, Guizhou Normal University, Guiyang 550001, P. R. China \\ ${ }^{3}$ Institute of Biology, Guizhou Academy of Sciences, Guiyang 550001, P. R. China \\ ${ }^{4}$ Guizhou Botanical Garden, Guiyang, Guizhou 550000, P. R. China
}

Received: 27 September 2020

Accepted: 12 November 2020

\begin{abstract}
Rocky desertification is seriously restricting the sustainable development of agricultural production and tourism industry in karst regions. This study focus on the characteristics of rocky desertification and its main driving factors on non-tillage lands in Houzhai River Basin of southwestern China. Artificial neural networks (ANNs) were employed in this study to identify the importance of different environmental factors on rocky desertification. The results showed that the rock outcrops in non-tillage lands ranged from 0.00 to $91.12 \%$ with a mean value of $19.10 \%$ in the Houzhai River Basin, and the rates of rock outcrops among different types of vegetation were ordered as: shrub grasslands $(35.30 \%)>$ arbor forestlands $(30.07 \%)>$ shrublands $(23.13 \%)>$ arbour-shrub mixed forestlands $(27.54 \%)$. With increases in slope gradient and altitude, the cover rate of rock outcrops became higher and rocky desertification became more serious. Based on ANNs analysis, the correlation coefficients between observed and predicted values of remaining data sets ranged from 0.828 to 0.998 , which indicated that the importance of altitude, slope gradient, gravel content and soil bulk density are the dominant factors affecting soil erosion and thereby leading to the occurrence of rocky desertification in the Houzhai River Basin. In addition, ANNs combine with environmental factors can be a feasible way to predict tendency of rocky desertification in a karst regions.
\end{abstract}

Keywords: rock outcrop, karst, rocky desertification, affecting factor, artificial neural networks

\footnotetext{
\#These authors contributed equally to this work.
}

*e-mail: yczhou@gzu.edu.cn 


\section{Introduction}

Karst rocky desertification is a worldwide ecological problem, especially in China [1]. It is a type of land degradation characterized by vegetation and soil degradation, land productivity decline and the loss of ecosystem function, and the rock outcrop is the most apparent result. Such desertification is of great harm and is restricting the sustainable development of societies and economies [2]. The main problems caused by rocky desertification are soil loss, the reduction of arable lands, occurrences of natural disasters, and land deterioration. It is a large obstacle for construction of ecological civilization and building a harmonious society [3]. Karst rocky desertification is the source of disaster and the root of poverty in karst regions. Urgent needs from residents are carry out series comprehensive treatments against rocky desertification, while restore and rebuild the degraded ecosystem in karst rocky desertification areas [4]. Guizhou Province is also one of the largest and most highly populated areas with typical karst in the world [5]. The karst area in Guizhou province is up to $129,000 \mathrm{~km}^{2}$, accounting for $73.6 \%$ of the total land area of the province [6]. Karst habitats in this region are discontinuous, have shallow soil, experience poor soil and water conservation, and contain limited arable land [7]. Reclamation of forestlands to expand arable land for the aim of releasing the conflict had seriously destroyed forest vegetation in karst areas, which further aggravated the rocky desertification in this region.

Karst areas are characterized by low environmental capacity, weak anti-disturbance ability, low stability and poor self-adjustment ability [8]. Irrational disturbance by human beings with the rapid development of society has led to sharp degradation of soil quality and the occurrence of rocky desertification in karst regions [9-10]. In southwest China, the area of rocky desertification covers at least $105,100 \mathrm{~km}^{2}$, and rocky desertification and soil erosion have become the most serious problems in this area, especially in Guizhou Province [11]. Since the beginning of $21^{\text {st }}$ century, great attention has been given to prevention and control of rocky desertification in karst areas to recover or rebuild ecosystems [12]. Some scholars believe that the key step of karst mountain forest restoration is to realize the ecological optimization of the human-land system; some of other scholars emphasized on vegetation restoration is the primary task of ecological restoration and the prevention and control of rocky desertification in karst areas, claiming that different forest restoration measures should be adopted according to the specific types of rocky desertification [11, 13]. Vegetation restoration in karst areas can improve not only the landscape but also the degree of land degradation. In the process of natural succession from the early to the climax community, the lands underwent through shrub-grassland, shrub-land, arbour-shrub mixed forestland and arbor forestland [14]. Meanwhile, there is also an interaction between soil and vegetation succession in response to those environmental variations [15]. As a result, the cover rate of rock outcrops decreases gradually, and the ecological environment improves. Soil erosion is alleviated, and land productivity increases gradually [2].

The issue of prevention and control of rocky desertification in karst areas has aroused great concern, and the work is mainly focused on the restoration of vegetation and the reconstruction of the ecosystem [16]. Most previous investigations concern the status of rocky desertification and its causes and recovery strategies [17]. The status of rocky desertification has been well studied. The causes of rocky desertification have been widely discussed, and most studies in the literature conclude that human disturbance (mainly agricultural activity) is the primary factor [18]. However, some studies have indicated that human disturbance did not lead to soil erosion but rather contributed to soil conservation [19-20]. Some studies also reported the contribution of environmental factors to soil erosion or rocky desertification based on the single factor or a simple statistical analysis. However, karst lands are ecological systems, and the occurrence of rocky desertification was associated with many factors including geological, environmental and anthropogenic factors [3, 21-22]. Few studies present information/ theory on the occurrence of rocky desertification in an integrative analysis.

At present, study on remediation of rocky desertification and occurrence of forest restoration are mainly limited to tree species structure and landscape change [23]. The scientific validity and effectiveness of the restoration of woodland in rocky desertification areas have been questioned. It is of great importance to clarify the basic driving force of soil erosion and rocky desertification in karst areas. The main objectives of this research are as follows: (a) to clarify the rocky desertification status of karst landforms under different vegetation, and (b) to study the factors contributing to soil erosion and rocky desertification in a karst area based on statistical analysis and artificial neural networks (ANNs).

\section{Materials and Methods}

\section{Study Region}

Houzhai River Basin $\left(105^{\circ} 40^{\prime} 43^{\prime \prime} \sim 105^{\circ} 48^{\prime} 2^{\prime \prime} \mathrm{E}\right.$, $26^{\circ} 12^{\prime} 29^{\prime \prime} \sim 26^{\circ} 17^{\prime} 15^{\prime \prime} \mathrm{N}$ ) is a karst plateau basin in Guizhou Province [24]. It covers an area of $72 \mathrm{~km}^{2}$, and the altitude of this area ranges from 878.8 1495.6 m. In the studied area, land use includes arid land, paddy land, uncultivated land, arbor forest land, arbor-shrub forest land, shrub land, shrub-grass land, artificial fruit forest land and grassland. The non-tillage land is about $40.77 \mathrm{~km}^{2}$ accounting for $56.63 \%$ of the total area in the Houzhai River Basin. The ecosystem types mainly include montane elfin forest, coniferous and 


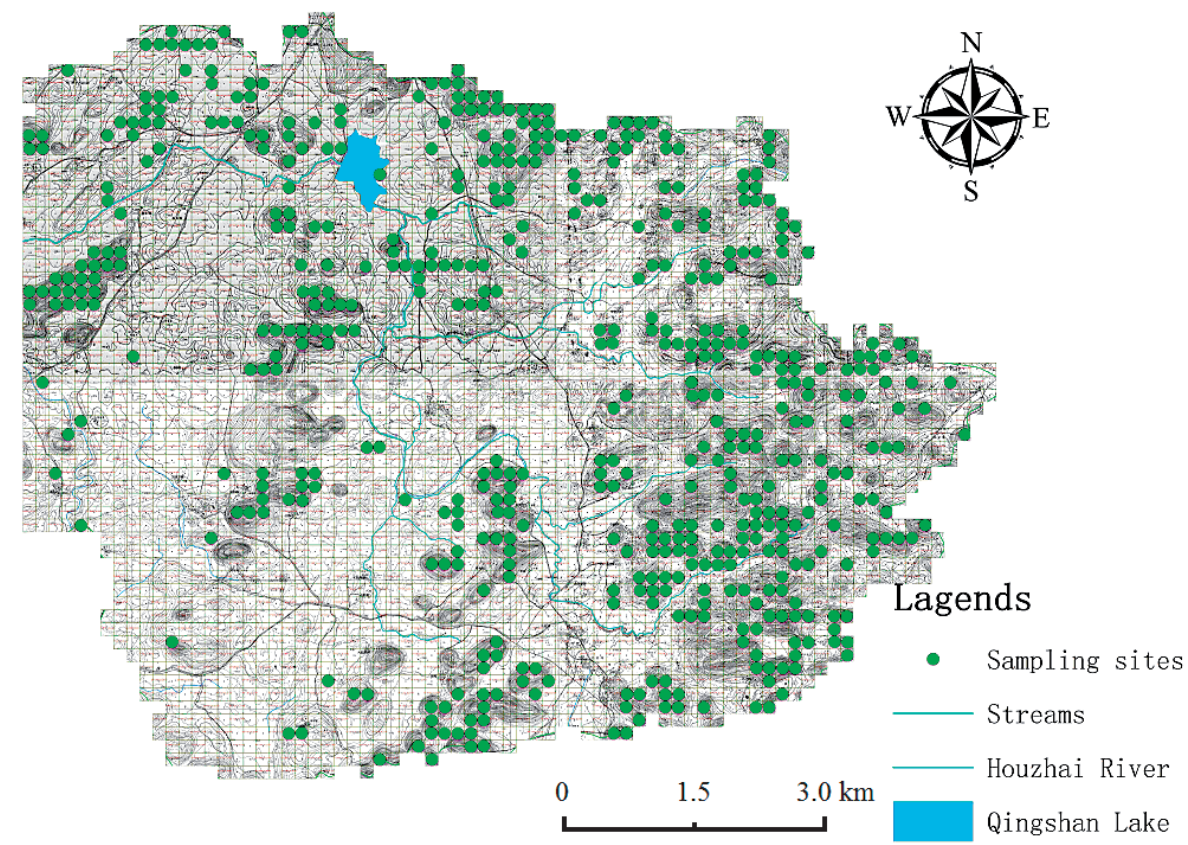

Fig. 1. Distribution of investigating and sampling sites.

broad-leaved mixed forest, and evergreen broad-leaved forest. Soils are mainly Leptosols, Ferralsols and Anthrosols (IUSS Working Group WRB, 2014). The physicochemical characteristics of special carbonates result in shallow soil or with high cover of rock outcrops. The soil is often separated into discontinuous patches by rocks. The physicochemical properties show a high degree of spatial heterogeneity [2].

\section{Soil Sampling}

Sampling sites were designed using ArcGIS 10.3 on a relief map based on the grid method, and the designed scale was $150 \mathrm{~m}$. Total of 1,3180 grids were delineated, and 442 of those grids were non-tillage land. Sampling sites were located at the centre of each non-tillage grid [25]. Soil thickness, altitude, slope gradient, slope position, slope aspect, soil types, parent rock, vegetation and microhabitat of each non-tillage grid were investigated. Soil bulk density (SBD) was determined in the field with the cylindrical core method, and rock outcrops (rock exposure rate) were measured by linear interception using tape [26]. Simultaneously, top soils $(0-20 \mathrm{~cm})$ were collected and saved in selfsealing plastic bags. Soil samples were transferred to the laboratory, air dried at room temperature, and then ground and sieved to test and remove the gravel fraction $(>2 \mathrm{~mm})$. The resulting materials were ground into powders and saved until analysis of soil organic matter (SOM).

\section{Analytical Procedure and Statistical Analysis}

Total SOC levels were determined by $\mathrm{K}_{2} \mathrm{Cr}_{2} \mathrm{O}_{7}$ oxidation followed by titration with $0.10 \mathrm{~mol} \mathrm{~L}^{-1}$
$\mathrm{FeSO}_{4}$, and $10 \%$ repetition was conducted [27-29]. Data were managed and treated with Microsoft Excel 2003 (Microsoft, Redmond, WA, USA). Statistical analysis was performed with the SPSS 18.0 (IBM, Armonk, NY, USA) and Arc Map 10.3 (ESRI, Redlands, CA, USA).

\section{Prediction of Rock Outcrop Cover Based on Environmental Factors}

ANNs are major artificial intelligence approaches derived from the operation of biological neurons. ANNs can solve multivariate non-linear problems with a suitable amount of data and an appropriate training algorithm [30]. In this study, artificial neural networks (ANNs) were used to predict the occurrence of rocky desertification on the basis of slope position, slope gradient, slope aspect, altitude, soil organic matter, gravel, soil bulk density, soil thickness, parent rock, microhabitat, soil type and vegetation. We assigned $60 \%$ of 442 data sets for training, and the remaining $40 \%$ of data sets were for prediction. As the prediction from ANNs is not stable, we repeated the process for 10 times.

\section{Results and Discussions} General Information on Rock Outcrops of
Non-Tillage Land in the Studied Basin

According to the field investigation information, 442 of 1,3180 designed grids were non-tillage land. Therefore, the studied region was approximately $9.95 \mathrm{~km}^{2}$, accounting for $13.90 \%$ of the total area of the Houzhai River Basin. The frequency distribution 


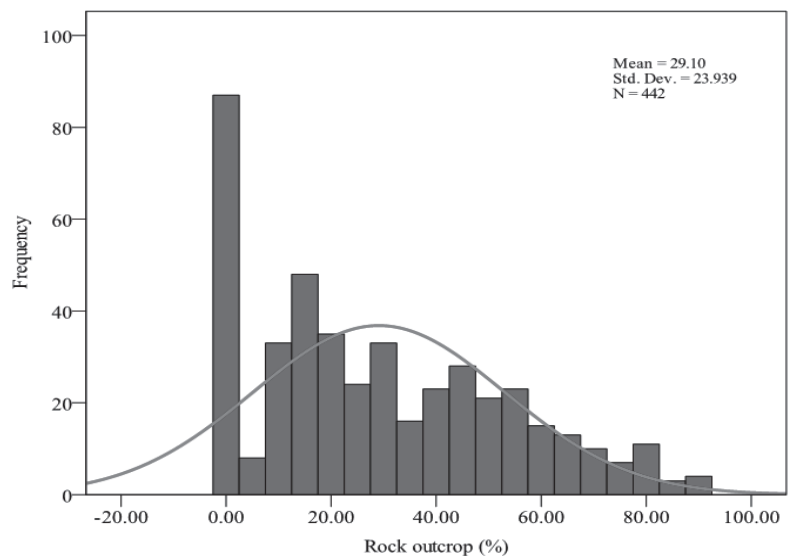

Fig. 2. Rock outcrops of non-tillage lands in karst river basin.

of rock outcrops of non-tillage land in the Houzhai River Basin is shown in Fig. 2. The rock outcrops of non-tillage lands in the basin ranged from $0.00 \%$ to $91 \%$ with a mean value of $29.10 \%$. The coefficient of variation was $23.94 \%$, which indicates moderate spatial variability. The results of a K-S test showed that the rock outcrop cover in the non-tillage lands of the study area was partially normally distributed $(\mathrm{p}<0.001)$ (Fig. 2).

\section{Rock Outcrops in Non-Tillage Land with Different Vegetation}

In the Houzhai River Basin, the areas of arbor forestland (AFL), arbour-shrub mixed forestland (ASFL), shrubland (SL) and shrub grassland (SGL) were approximately $2.40 \mathrm{~km}^{2}, 1.22 \mathrm{~km}^{2}, 3.76 \mathrm{~km}^{2}$ and $1.58 \mathrm{~km}^{2}$, respectively. The mean rock outcrop cover of non-tillage lands with different vegetation ranged from $0.00 \%$ to $91.00 \%$, and their variance ranged from $506.74 \%$ to $676.01 \%$ (Table 1 ). In the study area, a large number of rocks are exposed to the surface, and the soil is divided into patches of different sizes in different non cultivated areas, resulting in the discontinuity of soil cover. Obviously, significant differences existed among non-tillage lands with different vegetation. The mean rock outcrop of shrub grasslands $(35.30 \%)$ was the highest, followed by that of arbor forestlands (30.07\%), and the mean rock outcrop of arbour-shrub mixed

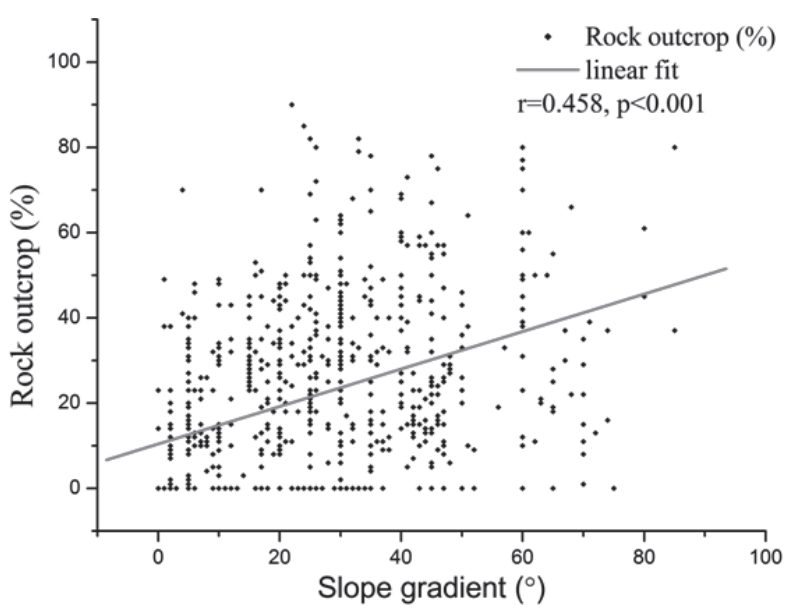

Fig. 3. Relationship between slope gradient and rock outcrop of non-tillage lands.

forestlands $(23.13 \%)$ was lowest, just behind shrublands (27.54\%).

\section{Relationships Among Environmental Factors and Rock Outcrops of Non-Tillage Lands in the Houzhai River Basin}

As shown in Fig. 3, there was a close relationship between slope gradient and rock outcrop cover of nontillage lands in the Houzhai River Basin ( $r=0.458$, $P<0.001)$. Along with an increase in the slope gradient, rock outcrop cover increased. This probably means that slope gradient is a critical driving force causing rocky desertification in karst areas. As shown in Fig. 4, rock outcrops of non-tillage lands in the Houzhai River Basin increased with the increase in altitude, and the Pearson correlation coefficient reached $0.531(P<0.001)$.

To study the relationship between slope position and rock outcrop cover of non-tillage lands, the sampling sites were divided into 7 groups including nek, flatlands, bottomlands, foot slope, back slope, shoulder slope and summit according to their locations (Fig. 5). The mean rock outcrop of non-tillage lands at different positions follows the order foot slope $(32.39 \%)>$ shoulder slope $(31.21 \%)>$ back slope $\quad(30.49 \%)>$ summit $\quad(27.87 \%)>$ bottomlands $(24.35 \%)>$ nek $(23.08)>$ flatlands $(1.67 \%)$.

Table 1. Rock outcrop status under different vegetations (\%).

\begin{tabular}{|c|c|c|c|c|c|c|}
\hline Forestlands & $\mathrm{N}^{*}$ & Minimum & Maximum & Mean & Std. Error & Variance \\
\hline Arbor forestland & 151 & 0.00 & 80.00 & 30.07 & 2.12 & 676.01 \\
\hline Arbor-shrub mixed forestland & 54 & 0.00 & 85.00 & 23.13 & 3.50 & 661.62 \\
\hline Shrub land & 167 & 0.00 & 90.00 & 27.54 & 1.66 & 458.70 \\
\hline Shrub grassland & 70 & 0.00 & 91.00 & 35.30 & 2.69 & 506.74 \\
\hline
\end{tabular}

$* \mathrm{~N}$ is the number of grids with different vegetations. 


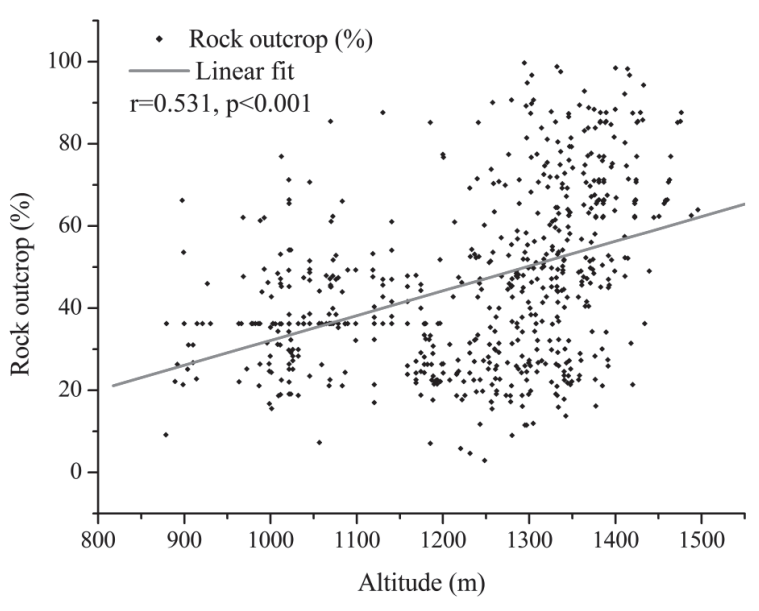

Fig. 4. Relationship between altitude and rock outcrops of nontillage lands in the Houzhai River Basin.

\section{Effects of Environmental Factors on Rock Outcrops of Non-Tillage Lands}

Fig. 6 presents an intuitive picture of the redundancy analysis of rock outcrops and environmental factors. The angles among rock outcrop, slope, altitude and soil organic matter are small. These angles are in the same quadrant, which indicates that there is a strong positive correlation among them. The line length of environmental factors presents the connection strength between rock outcrop cover and environmental factors. If the line is longer, then that correlation is greater. The smaller the angle is, the higher the correlation is. As shown in Fig. 6, gravel also has a positive effect on rock outcrop cover of non-tillage lands in the studied basin. However, soil bulk density, soil thickness and vegetation have negative effects on rock outcrop cover. The Houzhai River Basin is a typical small plateau karst basin with diverse topography and landform. In the basin, the rock outcrop cover ranges from $0.00 \%$ to

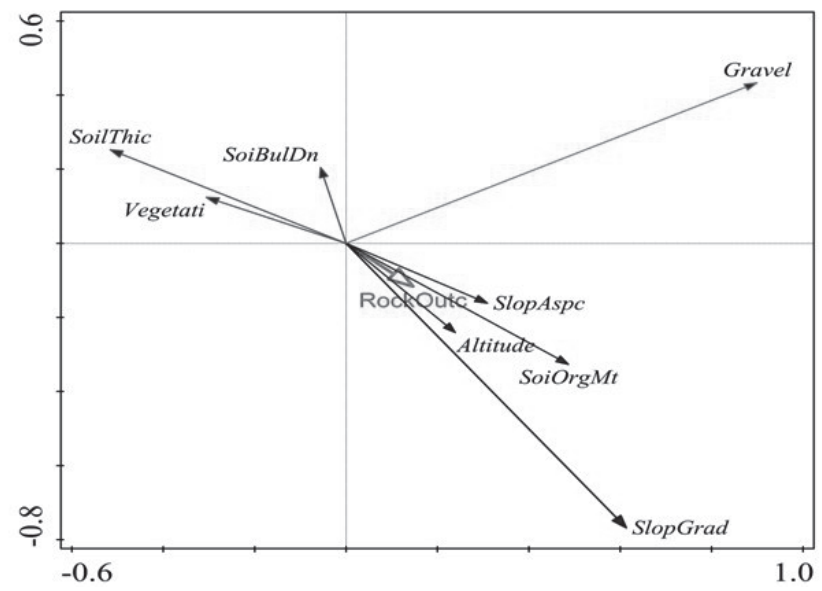

Fig. 6. Redundancy analysis of rock outcrops and environmental factors (note: SoilThic, soil thickness; SoiBuDn, soil bulk density; Vegetati, vegetation; RockOutc, rock outcrop; SlopAspc, slope aspect; SoiOrgMt, soil organic matter; slopGrad, slope gradient).

$91.00 \%$ with a mean value of $29.10 \%$, suggesting high spatial heterogeneity. It is found that topographical factors (including slope gradient, slope aspect and altitude) and soil factors (including gravel, soil bulk density and soil organic matter) are of complexity, which influences the cover rate of rock outcrops by difference degree and followed as: slope aspect>soil organic matter $>$ altitude $>$ slope gradient $>$ rock outcrops $>$ soil bulk density $>$ soil thickness $>$ vegetation (Fig. 6).

The terrain condition, like slope position, altitude and slope gradient, are important factors for the form of rock outcrop. On the one hand, increase in altitude leads to increase in slope gradient in the karst river basin. As mentioned in results (Figs 3 and 5), there was a close relationship between slope gradient and rock outcrop cover of non-tillage lands in the Houzhai River Basin. On the other hand, altitude is associated with the variation in vegetation, which is of great importance to soil conservation as verified by the range of shrub

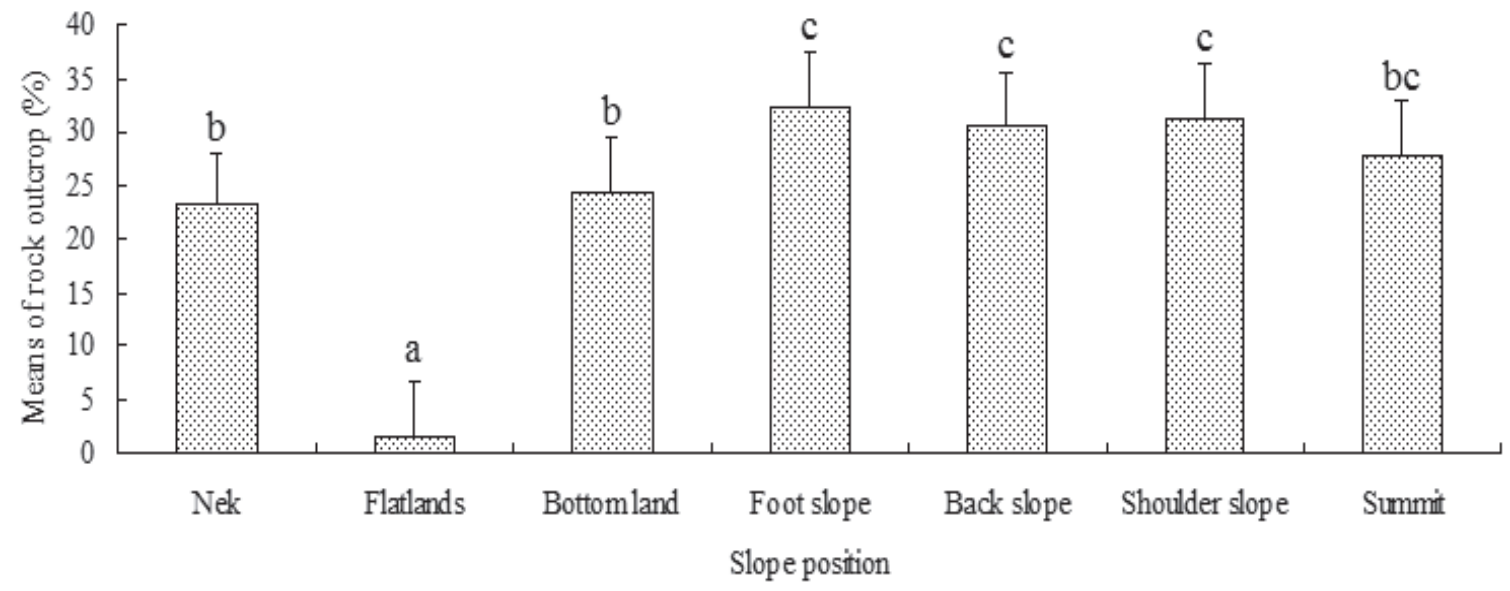

Fig. 5. Rock outcrops of non-tillage lands at different slope position in study region (no significance between plots with same letter). 
grasslands $\quad(35.30 \%)>$ arbor forestlands $\quad(30.07 \%)>$ shrublands $(27.54 \%)>$ arbour-shrub mixed forestlands (23.13\%) in Houzhai River Basin.

\section{Rock Outcrop Prediction Based on Environmental Factors with Artificial Neural Networks}

In the present study, 442 sets of data, including different environmental factors, were used to predict soil thickness with ANNs. A total of $60 \%$ of the data was used for model training, and the remaining $40 \%$ of the data (validation data) was used for prediction. The correlation coefficients between field-tested values and predicted values of remaining data sets ranged from 0.828 to 0.998 (10 times for training) with a mean value of 0.934 (Fig. 7a), which suggests that this approach is a feasible way to predict the occurrence of rocky

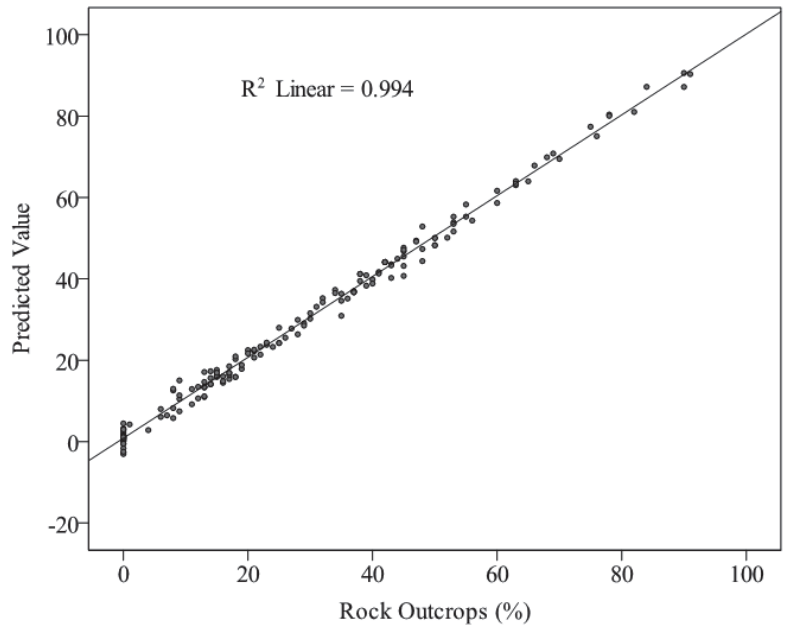

Fig. 7a). Prediction of rocky desertification based on environmental factors: linear correlation between measured value and predicted value of rock outcrop.

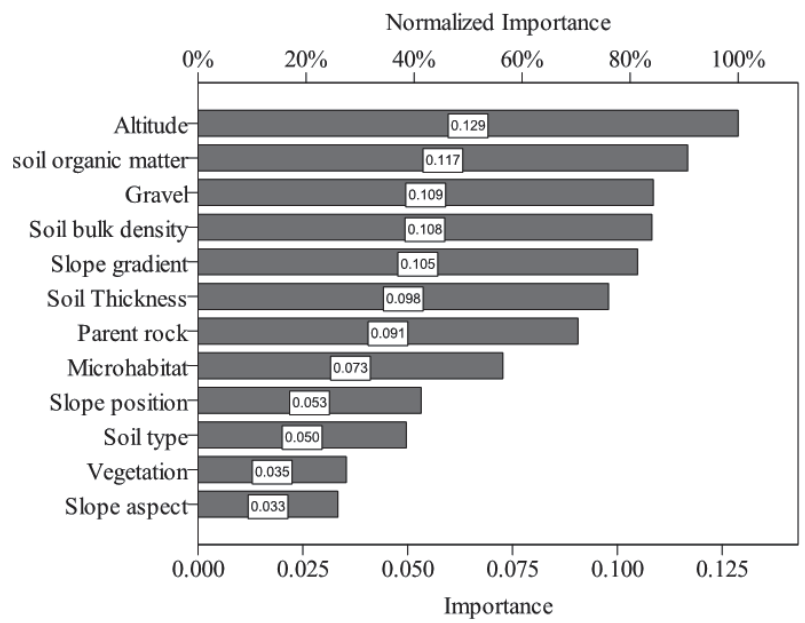

Fig. 7b). Prediction of rocky desertification based on environmental factors: importance of different factor in prediction. desertification in karst river basins with the examined factors. As showed in Fig. 7b), the normalized importance of altitude, soil organic matter, gravel, soil bulk density, slope gradient, soil thickness, parent rock, microhabitat, slope position, soil genus, vegetation and slope aspect was $0.129,0.117,0.109$, $0.108,0.105,0.098,0.091,0.073,0.053,0.050,0.035$ and 0.033 , respectively. It is believed that altitude, soil organic matter, gravel, soil bulk density and slope gradient are primary factors for the prediction of rocky desertification of non-tillage lands in the Houzhai River Basin.

\section{Integrated Analysis of Rocky Desertification in Karst Areas}

In karst areas, rock outcropping is influenced by many factors including geographic characters and soil quality [28]. Plants affect the input and output of soil organic matter by returning and absorbing the nutrients needed in the soil. In addition, soil physical and chemical properties are influenced by the vertical distribution of plant roots [31]. Therefore, vegetation cover is a critical factor to soil quality. The degree of rocky desertification can indirectly or directly affect the soil organic matter content, and soil organic matter content also affects the occurrence of rocky desertification by affecting soil properties or quality [32]. First, lands with a high degree of rocky desertification are always characterized by microhabitats of gullies, crevices and stone pits, and these microhabitats are beneficial to the retention and accumulation of soil organic matter [33]. Second, rock outcrop cover is one of the two key potential factors that affect land use in the river basin (the other being soil thickness), while soil organic matter is closely related to land use [15]. Therefore, the main factors that drive rocky desertification in the Houzhai River Basin are altitude and slope. To some extent, the gradient is determined by altitude. However, in addition to the slope, altitude also determines the microclimate and vegetation coverage [34]. Those factors are also dominant in the process of soil formation [35]. They not only dominate the redistribution of water and heat resources over the land surface and soils but also affect the material cycling and intensity of soil ecological systems, which has an important influence on the process of soil erosion, and soil erosion is an important factor in the occurrence of rocky desertification [36]. The terrain situation in the Houzhai River Basin fluctuates, and the landform is complex and varied [37].

At the same time, the slope gradient is an important factor in karst areas as we indicated the mean rock outcrop of non-tillage lands at different positions follows the order foot slope $(32.39 \%)>$ shoulder slope $(31.21 \%)>$ back slope $(30.49 \%)>$ summit $\quad(27.87 \%)>$ bottomlands $(24.35 \%)>$ nek $(23.08)>$ flatlands $(1.67 \%)$. The slope gradient has a direct effect on soil water holding capacity, soil moisture content and soil erosion 
processes leading to spatial heterogeneity of vegetation and soil nutrients. In addition, slope gradient is an important factor in determining the arrangement of land use in karst areas. It is believed that discrepancies in rock outcrop cover of non-tillage lands at slope positions were mainly caused by slope gradient and intensity of surface runoff [38]. For flatlands, slope gradient and surface runoff are very low, and soil erosion is light. From foot slope to shoulder slope, slope gradient increased gradually; in contrast, surface runoff intensity decreased gradually from foot slope to shoulder slope. Therefore, rock outcrop cover of non-tillage lands at the back slope is lower than that of non-tillage lands at both the shoulder slope and foot slope. The degree of rocky desertification in the basin is quite different among different terrain situations [34]. Therefore, it is necessary to attach great importance to the effect of topographic factors in the study and prevention of the rocky desertification in this region [39].

In addition, human activities are also another factor affecting the occurrence of rocky desertification in karst areas [40]. The expansion of population and unreasonable land policies lead to forest destruction and steep slope reclamation, which bring great pressure on the ecological environment. Before the 1990s, the study area was affected by historical events such as the movement of dividing and reserving mountains [41]. A large number of forests were cut down, steep slopes were reclaimed, and the proportion of steep slopes and steep slopes cultivated land increased rapidly [42]. After 1990s, under the guidance of national policies, ecological restoration projects such as the construction of protective forest system in the middle and upper reaches of the Yangtze River have been carried out, and the proportion of cultivated land on steep slopes and steep slopes has declined rapidly [43]. The increase of forest and grassland and the decrease of cultivated land greatly promote the ecological restoration of karst ecological fragile area. Therefore, in the southwest karst area where the ecological environment is extremely fragile, the main and effective means of ecological restoration in the future are to carry out the national ecological restoration project construction, develop the secondary and tertiary industries, and optimize and upgrade the industry.

\section{Conclusions}

The rock outcrops in non-tillage lands of the Houzhai River Basin ranged from $0.00 \%$ to $91.00 \%$ with a mean value of $29.10 \%$. There were significant differences among non-tillage lands with different types of vegetation, and the following ranking was observed: shrub grasslands $(35.30 \%)>$ arbor forestlands $(30.07 \%)>$ shrublands $\quad(23.13 \%)>$ arbour-shrub mixed forestlands (27.54\%). Topography, soil quality and vegetation are the main factors affecting the occurrence of rocky desertification in karst areas. The intensity of effects of the studied factors followed the order slope gradient $>$ soil organic matter $>$ altitude $>$ soil aspect $>$ gravel $>$ soil bulk density $>$ soil thickness $>$ vegetation. This approach is a feasible way to predict the occurrence of rocky desertification based on environmental factors. The Pearson correlation coefficients ranged from 0.828-0.998 (ten times), with a mean value of 0.934 . The comprehensive analysis of the prediction of rocky desertification by various environmental factors shows that altitude, slope gradient, gravel content and soil bulk density are the main factors affecting the occurrence of rocky desertification in the Houzhai River Basin.

\section{Acknowledgements}

This work was financially supported by the First-class Discipline Construction Project of Guizhou Province (GNYL [2017]007); the Project funded by China Postdoctoral Science Foundation (2020M673582XB); the Science and Technology Plan Project of Guizhou Province ([2019]2840; [2019]1217); and the Doctoral Research Fund of Guizhou Normal University [No. GZNUD[2017]11].

\section{Conflict of Interest}

The authors declare that they have no conflicts of interest concerning this article.

\section{References}

1. TIAN Z., WU X.Q., DAI E.F., ZHAO D.S. SOC storage and potential of grasslands from 2000 to 2012 in central and eastern Inner Mongolia, China. J Arid Land, 8, 364, 2016.

2. CLEMENTS R., SODHI N.S., SCHILTHUIZEN M., NG P.K.L. Limestone Karsts of Southeast Asia: Imperiled Arks of Biodiversity. Bioscience, 56 (9),733, 2006.

3. TONG X.W., WANG K.L., BRANDT M, YUE Y.M., LIAO C.J., FENSHOLT R. Assessing future vegetation trends and restoration prospects in the karst regions of southwest china. Remote Sens-Basel 8, 357, 2016.

4. FAN Z., LI J., YUE T., ZHOU X., LAN A.J. Scenarios of land cover in karst area of southwestern china. Environ Earth Sci 74 (8), 6407, 2015.

5. LU X., TODA H., DING F., FANG S.Z., XU H.G. Effect of vegetation types on chemical and biological properties of soils of karst ecosystems. Eur J Soil Sci, 61 (3), 49, 2014.

6. LONG D., SHEN Y., SUN A., HONG Y., LONGUEVERGNE L., YANG Y.T., LI B., CHEN L. Drought and flood monitoring for a large karst plateau in southwest china using extended grace data. Remote Sens Environ, 155, 145, 2014.

7. HUANG X.F., HONG J., ZHANG J.C. Research on soil quality of small watershed in Karst area. Journal of Guizhou Normal University (Natural Sciences), 36(4), 18, 2018 [In Chinese].

8. PENG J., XU Y.Q., ZHANG R., XIONG K.N., LAN A.J. Soil erosion monitoring and its implication in a limestone 
land suffering from rocky desertification in the Huajiang canyon, Guizhou, southwest China. Environ Earth Sci, 69 (3), 831, 2013.

9. TONG X.W., WANG K.L., Yue Y.M., BRANDT M., LIU B., ZHANG C.H., LIAO C.J., FENSHOLT R. Quantifying the effectiveness of ecological restoration projects on longterm vegetation dynamics in the karst regions of southwest china. Int J Appl Earth Obs, 54, 105, 2017.

10. WANG J., WANG K.L., ZHANG M.Y., ZHANG C.H. Impacts of climate change and human activities on vegetation cover in hilly southern china. Ecol Eng, 81, 451, 2015.

11. WANG S.J., LIU Q.M., ZHANG D.F. Karst rocky desertification in southwestern china: geomorphology, land use, impact and rehabilitation. Land Degrad Dev, 15 (2), 115, 2004.

12. XU E.Q., ZHANG H.Q. Characterization and interaction of driving factors in karst rocky desertification: a case study from Changshun, China. Solid Earth, 5, 1329, 2014.

13. DEBINSKI D.M., JAKUBAUSKAS M.E., KINDSCHER $\mathrm{K}$. Montane meadows as indicators of environmental change. Environ Monit Assess, 64 (1), 213, 2000.

14. CHEN X.B., ZHENG H., ZHANG W., HE X.Y., LI L., WU J.S., HUANG D.Y., SU Y.R. Effects of land cover on soil organic carbon stock in a karst landscape with discontinuous soil distribution. Journal of mountain science, 11 (003), 774, 2014.

15. JIANG Z.C., LIAN Y.Q., QIN X.Q. Rocky desertification in Southwest China: impacts causes and restoration. Earth -Sci Rev, 132, 1, 2014.

16. BRINKMANN R., PARISE M. Karst Environments: Problems, Management, Human Impacts, and Sustainability: An Introduction to the Special Issue. J Cave Karst Stud, 74 (2), 135, 2011.

17. QI X.K., WANG K.L., ZHANG C.H. Effectiveness of ecological restoration projects in a karst region of southwest china assessed using vegetation succession mapping. Ecol Eng, 54, 245, 2013.

18. LI Y.B., SHAO J.A., YANG H., BAI X.Y. The relations between land use and karst rocky desertification in a typical karst area, china. Environ Geol, 57 (3), 621, 2009.

19. PENG T., WANG S.J. Effects of land use, land cover and rainfall regimes on the surface runoff and soil loss on karst slopes in southwest China. Catena, 90, 3, 2012.

20. SOLAIMANI K., MODALLALDOUST S., LOTFI S. Investigation of land use changes on soil erosion process using geographical information system. Int J Environ Sci Te, 6 (3), 415, 2009.

21. YANG Q.Y., JIANG Z.C., MA Z.L., LUO W.Q., XIE Y.Q., CAO J.H. Relationship between karst rocky desertification and its distance to roadways in a typical karst area of Southwest China. Environ Earth Sci, 70 (1), 295, 2013.

22. YUE Y.M., ZHANG B., WANG K.L. Spectral indices for estimating ecological indicators of karst rocky desertification. Int J Remote Sens, 31, 2115, 2010.

23. HOU W., GAO J., WU S., DAI E. Interannual variations in growing-season NDVI and its correlation with climate variables in the southwestern karst region of china. Remote Sens-Basel, 7 (9), 11105, 2015.

24. HUANG X.F., WANG S.J., ZHOU Y.C. Soil organic carbon change relating to the prevention and control of rocky desertification in Guizhou Province, SW China. Int J Global Warm, 15 (3), 315, 2018.

25. ZHANG Z.M., ZHOU Y.C., WANG S.J., HUANG X.F. Soil organic carbon density spatial distribution and influencing factors in a karst mountainous basin. Pol J Environ Stud, 26 (5), 2363, 2017.

26. ZHANG Z.M., ZHOU Y.C., WANG S.J., HUANG X.F. The soil organic carbon stock and its influencing factors in a mountainous karst basin in P. R. China. Carbonate Evaporite, 1, 2018.

27. WANG S.J., LI R.L., SUN C.X. How types of carbonate rock assemblages constrain the distribution of karst rocky desertified land in Guizhou Province, PR China: phenomena and mechanisms. Land Degrad Dev, 15(2), 123,2010

28. HUANG X.F., ZHOU Y.C., ZHANG Z.M. Carbon sequestration anticipation response to land use change in a mountainous karst basin in China. J Environ Manage, 228 (15), 40, 2018.

29. WANG Y.G., LI Y., YE X.H., CHU Y., WANG X.P. Profile storage of organic/inorganic carbon in soil: from forest to desert. Sci Total Environ, 408 (8), 1925, 2010.

30. LÓPEZ M.E., RENE E.R., BOGER Z., VERGA M.C., KENNES C. Modeling the removal of volatile pollutants under transient conditions in a two-stage bioreactor using artificial neural networks. J Hazard Mater, 324, 100, 2016.

31. WEI J.B., XIAO D.N., ZHANG X.Y., LI X.Z., LI X.Y. Spatial variability of soil organic carbon in relation to environmental factors of a typical small watershed in the black soil region, Northeast China. Environ Monit Assess, 121, 597, 2006.

32. ZHANG M.Y., WANG K.L., ZHANG C.H., CHEN H.S., LIU H.Y., YUE Y.M., LUFFMAN I., QI X.K. Using the radial basis function network model to assess rocky desertification in northwest Guangxi, China. Environ Earth Sci 62 (1), 69, 2011.

33. BAI J.H., ZHAO Q.Q., LU Q.Q., WANG J.J., YE X.F. Land-use effects on soil carbon and nitrogen in a typical plateau lakeshore wetland of China. Arch Agron Soil Sci, 60 (6), 817, 2014

34. SEPASKHAH A.R., AHMADI S.H., SHAHBAZI A.R.N. Geostatisticalanalysis of sorptivity for a soil under tilled and no-tilled conditions. Soil Tillage Res, 83 (2), 237, 2005.

35. DAY M. Challenges to sustainability in the caribbean karst. Geol Croat, 63, 149, 2010.

36. XIONG Y.J., QIU G.Y., MO D.K., LIN H., SUN H., WANG Q.X., ZHAO S.H., YIN J. Rocky desertification and its causes in karst areas: a case study in Yongshun County, Hunan Province, China. Environ Geol, 57 (7), 1481, 2009.

37. PARISE M, WAELE J.D., GUTIERREZ F. Current perspectives on the environmental impacts and hazards in karst. Environ Geol, 58 (2), 235, 2009.

38. LAL R. Soil carbon sequestration in China through agricultural intensification and restoration of degraded and desertified ecosystems. Land Degrad Develop, 13 (6), 469, 2002.

39. ZHANG Z.M., FRIEKE V.C., OU X.K., ROBERT D.W. Integration of satellite imagery, topography and human disturbance factors based on canonical correspondence analysis ordination for mountain vegetation mapping: a case study in Yunnan, China. Remote Sens-Basel, 6, 1026, 2014.

40. LI Y.B., XIE J., LUO G.J., YANG H., WANG S.J. The evolution of a karst rocky desertification land ecosystem and its driving forces in the Houzhaihe area. Open Journal of Ecology, 5 (10), 501, 2015. 
41. YING B., XIAO S.Z., XIONG K.N., CHENG Q.W., LUO J,S. Comparative studies of the distribution characteristics of rocky desertification and land use/land cover classes in typical areas of Guizhou province, China. Environmental Earth Sciences, 71 (2), 631, 2014.

42. ZHANG J.Y., DAI M.H., WANG L.C., ZENG C.F., SU W.C. The challenge and future of rocky desertification control in karst areas in southwest China. Solid Earth Discussions, 7 (1), 3271, 2016.

43. ZHOU Y.C., WANG S.J., LU H.M., XIE L., XIAO D. Forest soil heterogeneity and soil sampling protocols on limestone outcrops: example from SW China. Acta Carsologica, 39 (1), 117, 2010. 